\title{
Guarding Thought against Self-Destruction. Contradiction and Identity in Cohen and Hegel
}

\author{
Hartwig Wiedebach $\bowtie$ \\ 37, Georg-Boehringer-Weg, Goeppingen, 73033, Germany \\ \wiedebach@posteo.de
}

\begin{abstract}
Hermann Cohen's Logic of Pure Knowledge and G. W. F. Hegel's Science of Logic each use in their way the means of thought of negation and contradiction to unfold the philosophical dynamic: a fragile interplay between self-endangerment and self-preservation of thought. Here, the proximity and difference of the two authors are extended. The proximity lies in methodological negativism. The difference is in the significance of the principle of continuity. According to Cohen and Hegel as well, thinking proceeds exclusively, as Kant called it, synthetically. The exclusion of contradiction, limited to analytical judgments, has only marginal significance. But the commonality does not eliminate the differences. As Hegel puts it, contradiction is a principle of mediation and finally results in "self-dissolution"; it carries within itself a direction of logical "reconciliation." Per Cohen, contradiction is a principle of "annihilation" (annihilatio) of approaches to a determination that threatens any form of "identity." The turn Hegel put in contradiction itself, regarding in it a unity of positivity and negativity, has no direct counterpart in Cohen. Nevertheless, for him, too, the "judgment of contradiction" becomes the active basis of all cognitive thought. By exercising a contradictiondestroying "activity," the judgment of contradiction "protects," indeed "generates," the real possibility of cognition. The annihilation of the non-identical sets free the fundamental "judgment of origin" with which cognition finds its beginning. The principle of continuity taken over from Leibniz corresponds to it. Just this principle has now again no direct correspondence with Hegel.
\end{abstract}

Keywords: affirmation, annihilation, continuity, contradiction, dialectic, identity, Jacob Gordin, judgement, laws of thought, negativism, origin

\section{Article history:}

The article was submitted on 16.05.2021

The article was accepted on 04.09.2021

(C) Wiedebach H., 2021

This work is licensed under a Creative Commons Attribution 4.0 International License https://creativecommons.org/licenses/by/4.0/ 
For citation: Wiedebach H. Guarding Thought against Self-Destruction. Contradiction and Identity in Cohen and Hegel. RUDN Journal of Philosophy. 2021;25(3):394-403. DOI: 10.22363/2313-2302-2021-25-3-394-403

The present article is a small contribution to the comparison of the logical designs of Cohen and Hegel. Several scholars have argued that the critical project of Kantian philosophizing can currently only reach its goal if it is extended to Hegel's methodological dispositions. I am thinking here especially of Christian Krijnen and Kurt Walter Zeidler, neither of whom, however, started with Hermann Cohen $[1 ; 2]$. For my part, I shall begin with Hermann Cohen. I am concerned, as sometimes before, with that aspect of thinking which gives our cognition the security of a valid beginning ${ }^{1}$. This refers to the protective " $n o$ " to everything that opposes an unambiguous, identical content of our cognition to itself. It is a purifying act, called by Cohen "the judgment of contradiction" [5. P. $104 \mathrm{ff}$.]. It protects, as we shall see, thought from self-destruction. Because of the decisive role Cohen assigns to it, his logic, according to my thesis, moves into striking proximity to Hegel's methodological negativism.

The Logic of Pure Knowledge begins with a meditation, as thinking begins. It is about principles, not yet about objects [6. P. 186]. The logic of principles comprises three so-called "judgments of the laws of thinking." The beginning is made by "The judgment of the origin." The origin of thinking lies - seemingly simple - in asking. But what is a "question"? For Cohen, it is itself a "kind of judgment" [5. P. 83]. Only on its basis does the approach to a determination arise. What we regard as a question must be formed in growing definition and certainty toward cognition. To become aware of this approach, means, in the words of Jakob Gordin, one of the important interpreters of Cohen's logic, to "generate a problem" [7. P. 117]. The problem is a scientifically oriented question. It comes to this, when a context of knowledge that has become self-evident becomes doubtful to us. Therein lies a claim that has not yet found an answer. However, it is about an answer. The questioning as a foundation, even as an anticipation of a new answer in dealing with the claim, is "The judgment of the origin."

Thinking turns away from the self-evident, seemingly given, in the direction of, as Cohen says: "nothing." It is the uncertain space that opens up in questioning and which is to be filled by answering. Therefore the nothing in which what seems to be given is passed is consequently relative: an indication of a new particularity within the knowledge of nature, different from the previous one. It is not a loss of approach, but the approach itself. Cohen, however, did not present a fundamental ontological mediation on being and nothingness. For him, the valid principle of the Critique of Pure Reason was that "all our knowledge begins with experience" [8.

\footnotetext{
${ }^{1}$ The present article complements two earlier articles: H. Wiedebach, "Widerspruch und Identität bei Cohen und Hegel. Schutz des Denkens vor Selbstvernichtung" [3], and also the first part in "Logic of Science vs. Theory of Creation: The 'Authority of Annihilation' in Hermann Cohen's Logic of Origin" [4].
} 
P. 33]. In the beginning, something is always thematic. To step back behind this experience-something in order to reflect on its transcendental-logical "springing forth" (Entspringen) [8] in distinction from that "lifting up" (Anheben) is not to look at a nihil negativum, at a creatio ex nihilo. Kant and Cohen, evidently different from Hegel, never seek a "representation of God [...] as he is in his eternal being before the creation of nature and of a finite spirit" [9. P. 31].

Cohen's metaphysical horizon of something (metaphysics in the sense of Kant's Metaphysical Foundations of Natural Science) already contains the determinability of its contents in itself. Therefore, Cohen does not speak of the origin "ex nihilo" but " $a b$ nihilo" [5. P. 84]. His crucial concept for gaining determination from determinability is continuity. Thereby quantitative continuity (the differential and integral calculus interpreted in terms of object logic - Cohen's "The Judgment of Reality" and "The Judgment of Allness"), although it can by no means make the beginning of logic, is both model and object-logical correlate to the principle logic of qualitative continuity. The differential-mathematically constituted "reality" thus radiates back to that which logically precedes it - a kind of retro-cipation, which we will also find in a different form in the relation between "contradiction" and "origin." The retro-cipation, however, is at the same time anti-cipation. The recognizing thinking accomplishes it by looking into the future and by pursuing a task.

The task of grasping knowledge thus requires that one turns away from the given and takes an "adventurous detour" [5. P. 84]. However, this adventure has its purpose in looking at something different from the previous and constituting it in its turn. The gaze into the "relative nothing" is followed by what Gordin has called a "reversal of turning away"2. The questioning of something is supposed to establish, even "generate," a new cognition. The logic of pure cognition unfolds this new justification into its numerous moments. Its 12 judgments altogether expose the meaning of the principle: "thinking is thinking of origin" [5. P. 36] — one could also say: thinking is thinking as the origin. "Judgment of origin" concerns only the point of first turning toward relative nothingness and thus the approach to knowledge. It is not yet the way back to new determinacy. Its product is consequently not an already grasped $\mathrm{A}$, but a mere $\mathrm{X}$ lying 'before' it [5. P. 83]. What comes about here is a determinable (Bestimmbares), a beginning something, an "intermediate thought" [5. P. 104].

Secondly, this first "judgment of the laws of thought" is followed by the "judgment of identity." Here, what so far hovers on the threshold between determinability (Bestimmbarkeit) and definability (Bestimmtheit), is taken more firmly into view. It is a first stopping point. Thinking takes hold of the $\mathrm{X}$ of the first "springing forth" (Entspringen), and thus places itself opposite of it, but only to

\footnotetext{
${ }^{2}$ Cf. Gordin (Umkehr der Abkehr) [7. P. 99]. This leads to a purely logical concept of the future, cf. Cohen [5. P. 63]
} 
fasten itself in it. It is a gesture of repetition, a re-flection of the beginning, towards a self-referential determinacy A. The sentence that expresses and confirms this is "A is A" [5. P. 95]. The act of thinking it symbolizes is a non-empty 'Tauto-Logos,' a formation and fixation of determination (Bestimmtheit) by identity (Selbigkeit) ${ }^{3}$.

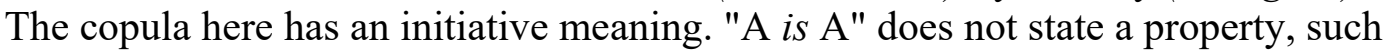
as "the house is house-like", but it sets the beginning to a being (Beginn zu einem Sein). Also, "A is A" does not express a comparison, in the sense that "A is (equal to) A" 4 . In the "judgment of identity," nothing can be compared yet.

Thus, with the "identity," we have the first setting of a fixed determination (Bestimmtheit) at all. According to Cohen/Gordin, this excludes that this A could be a contradiction in itself. This notion brings us to a crucial point for the dynamics of judgment. In the act of judgment, "A is A," there seems to be implied, especially when it is specifically accentuated, the possibility that A could also be non-A. The initiative expressed in the copula would then go into an anti-identical direction. The beginning of a being would be inverted into self-destruction since the evasion into a merely negative judgment like "the [existing] house is non-house-like" is excluded. The latter would at best result in a call to correct the previous predication. The initiative to a non-A instead, which is now in question, would go against the goal of initiating itself. The initiating of determination is in its turn a determined doing, and every determining gains its profile only by setting itself apart from a counterpart. For Cohen, too, Spinoza's "omnis determinatio est negatio" [all determination is negation] holds. Thus, the act of judgment "A is A" precisely to become valid - inevitably generates the thought of its opposite. Since it is about the act of determinacy at all, this opposite is not a possible other attribute but self-destruction. It is as if this danger would arise in the hedging foundation itself. Identity would be skeptically subverted: to think "A is A" would mean thinking of the A as a germ to a non-A, even if it should not be developed yet. Antilogic would arise in logic.

That is precisely how Hegel interpreted identity in his logic of essence: ${ }^{5}$ inevitably, a "difference" emerges at his reflection determination of identity, mediated by the immediacy of the A itself, and manifests the dialectical tension. It subsequently increases to an "alienating reflection" into the "opposition," which reaches its climax in the "contradiction." This, however, is at the same time peripeteia as it proves that its very unity of essence - precisely as the unified element "contradiction" — links the "positive" and the "negative" with each other. It is an active moment: connecting the contradictory, the "translation" of each "into its opposite." In this act of reflection, contradiction, for Hegel, leads to "self-dissolution" and opens the view to the "essence [...] as the reason" of this happening - a reconciliation that cancels the dialectical tension. - According to Cohen, however, and especially to Gordin, it is a "degradation of identity"

\footnotetext{
${ }^{3}$ Cf. [5. P. 94].

4 "Equality" according to Cohen is a concept of magnitude and belongs to the logic of objects; cf. [5. P. 102, 482-486].

${ }^{5}$ Hegel „Die Lehre vom Wesen“, the following is cited from Lasson [9. Bd. 2. P. 32, 36, 49, 51, 63].
} 
[7. P. 25] to impute such action to it. In their opinion, Hegel robs thinking of its solidity: in all forming, he allows for an equal power of self-destruction. If thinking grasps something, it has basically grasped nothing. This leads to no sustainable determination. According to Cohen, identity is a pure assurance (affirmatio) of an $\mathrm{A}$ as such, without a non-A germinating the A itself from within ${ }^{6}$.

Of course, Cohen cannot escape the power of annihilation. Thus, no sooner has the logic of pure cognition arrived at the A than a non-A emerges, and the seemingly straightforward illumination becomes iridescent. The A, it is said, needs a "protective means" against "falsifications of its content" [5. P. 106]. Strangely enough: the defense of non-A even becomes the driving force in judging in general. For otherwise, the "assurance (affirmatio)" [5. P. 96] cannot become certainty through identity. The protection of the $\mathrm{A}$ is carried out by the third step after "origin" and "identity": "the judgment of contradiction." It is an "instance of annihilation" [5. P. 106] vis-à-vis that possibility of "falsification" seemingly germinates in mere identity. Assurance (affirmatio) may be understood simultaneously as the dedication (dedicatio), as a positive 'bestowal' of determinacy. Negation enters the profile as abdication (abdicatio), as a negative 'denial' of determinacy endangering identity. And Cohen goes so far as to say: "More significant" than dedicatio "is the word abdicatio. And we are probably not mistaken in supposing that the latter might have led to the former" [5. P. 106].

A striking assumption: the judgment of annihilation seems to precede the judgment of identity! At the same time, Cohen links it with a pathos that lets one sense his opposition to Hegel: "Between A and a non-identical A there is no reconciliation for thinking. It must be annihilated to null, to nothingness, so that a judgment on its content becomes executable only in this direction" [5. P. 107]. "Only in this direction" means: the opposite of identity, the act of definability, is annihilated. Cohen continues evocatively, "It is the vital question of judgment that it is able to raise this instance in itself, the instance of annihilation" (ibid.). After all, truth is at stake - in the sense in which identity is a "law of thought of truth," contradiction and annihilation now form a "law of thought of untruth" [5. P. 115] This is not a question of error: "That would be psychological." No: "There is a falsehood (das Falsche) for logic" (ibid.). Untruth, self-destruction, must, just like truth, come 'positively' to the fore to be able to be regarded as destroyed in its turn.

Let us repeat it. What is to be annihilated: the self-destructive possibility of an immanent contradiction of identity in itself arises both 'before' and 'after' identity. Its defineability, since at the same time affirmation (affirmatio), seems to precisely exclude that. Cohen sees this dialectic, which reveals itself only to repeated reflection, as a menace, and it must be specifically confronted. Yet, his struggle against dialectics is dialectical in itself. Only when someone realizes this one can

\footnotetext{
${ }^{6}$ See [5. P. 97-100]. Cf. as an overview Helmut Holzhey's "Entzauberung des Pantheismus. Cohens Kritik an Hegels und Schellings Metaphysik" [10], and Wolfgang Bonsiepen's "Hegel und der Neukantianismus" [11].

${ }^{7}$ Here I will leave aside the fact that Cohen wanted to cite additional evidence concerning his Logic in Ethik des reinen Willens $\left(1904,1907^{2}\right)$ [12. P. 83-108], esp. p. 89.
} 
almost say: the initial appearance of the opposite of identity becomes transparent so that one can talk about a "judgment in content" that has not yet occurred. At first, one would think: a content can only come about as a determination of the kind of an A. It is impossible to negate the non-A "in content" - for the non-A cannot be a content by definition. Consequently, we do not have a "judgment in content" at all. Hence, Cohen also speaks of a "judgment before the judgment" [5. P. 106]. He determines this "judgment before the judgment" in as many as three places, also very emphatically therein, as the "activity of the judgment" [5. P. 107, 108, 116]. "It is judgment itself that denies this right and value to a content that presumes to become the content of judgment" [5. P. 107]. Only one kind of "presumed content" is conceivable here at most: precisely the false appearance that in identity lies its opposite.

His rejection is so fundamental that it leads us back to the "judgment of the origin." For a "content which presumes to become content of the judgment," without achieving this, can at best be thematized 'before' the identity, that is: only on the level of the first determinable. As soon as the first determinacy, i.e., identity, establishes itself, it covers that presuming content by its "A is A." Identity means one-sidedness. So, for its own sake, the danger must be traced and eliminated at the root of identity. Accordingly, Cohen writes: "There is no non-A, and there must be no non-A which, as distinguished from the nothingness of the origin (Nichts des Ursprungs), would have a closed content" [5. P. 107] ${ }^{8}$. However, the problem of non-A emerges only after the A has already become thematic. In this respect, the problem of contradiction arises after identity, and "the order of its use must not be confused" [5. P. 120]. Yet, the approach to non-A is transcendental-logically prior to identity, namely at the origin-nothing. The "judgment of identity" in turn presupposes the "judgment of contradiction" to itself.

This means: the danger of a 'closed' content in the shape of the non-A already arises with the initial question, that very first "kind of a judgment," and to deny exactly this closedness is the annihilation of the non-A. Indeed, 'closedness' would, in turn, secure the opposite undermining identity and thereby make it robust. Cohen cannot allow this to happen. So we must look back from the third of the Judgments of the Laws of Thought to the first one. Holzhey rightly remarks that the principle of contradiction is "directly connected with the introduction of the principle of origin" [6. P. 238]. Once again: the question about the non-A arises only 'after' the identity, but the answer must be sought 'before.' It is as if the scientific thinking organizes a phalanx of defense and annihilation, in the middle of which, even by means of which, the identical and therein one-sided A establishes itself.

III

Against this background, we have to look back at Hegel's definition of the essence of contradiction. Cohen's polemic loses its bite on closer inspection. Of course, even he would not doubt that Hegel also refers to generative, i.e., to

\footnotetext{
${ }^{8}$ Emphasis mine.
} 
synthetic thinking, so Kant. The "law of noncontradiction," limited to analytic judgments, interests neither of them more than marginally. However, once this common ground is established, the stylistic difference immediately catches the eye. In Hegel, the contradiction is regarded as a generating principle, in Cohen as a principle protecting generation. Hegel's positive reading, which sees in contradiction a unity of the positive and the negative and looks from it into the ground, has no explicit counterpart in Cohen. But he, too, ties the principle of contradiction to identity determination without an intermediate step. Its affirmation (affirmatio) succeeds because it is immediately followed by a counteraction (repugnatio) [5. P. 108], a negative attack against danger. 'Immediately following' means: the two judgments, first identity, then contradiction, do not flow into each other. They mark not only representationally but logically two successive steps. Doesn't this already prove a dialectical construction? A dialectic, which is confirmed by the fact that just the "judgment of contradiction" was determined as the "activity" of judging at all, that is, by Cohen's dialectic struggle against dialectics. His logic of judgment moves ever closer to Hegel's methodological negativism.

The threshold character of the contradiction in the logical system also confirms the proximity. Neither in Hegel nor Cohen is the goal of the contradiction on the same level as contradiction itself. In Hegel, contradiction belongs to the level of "entities or determinations of reflection," but it is a final threshold to a new dialectical triad - that of "reason." In Cohen, contradiction belongs to the level of "laws of thought," but it is a concluding threshold to the triad of a judgment of "mathematics." However, here again, the difference emerges. For neither does Hegel, with his triad of "reason," reflect on mathematical concepts including differential and integral calculus (rather, they belong to the preceding logic of being ${ }^{9}$ ). Nor, conversely, are Cohen's "Judgments of Mathematics" the reflection on a reason. Here, too, the seemingly clear difference opalesces. For Cohen's contradiction implies, as said, the turning back to the "judgment of the origin." Only this turning back, a kind of remembering reflection, lets the judgment of origin emerge as the ground of all judgment activity at all. For how else should the "origin" rule the cognitive thinking, including "the object-logical 'cognitions' [...]", i.e., act beyond its logical sphere? [6. P. 187 $]^{10}$. Only the proof that it in itself and through itself — one may well say with Hegel: 'in and for itself' - executes the contradiction-destroying "activity" of judging at all, "secures," "protects," even "generates" its fundamental meaning.

Here my exposition - for this time - comes to the limit. For now, Cohen's notion of "continuity" would have to be discussed, which, he also means here somewhat strikingly, "amply" replaces "what may be contained in the [Hegelian] reversal of opposites in terms of factual and historical stimuli" [5. P. 117]. Again, this sounds like mutual exclusion. Again, the details look different. Continuity

\footnotetext{
${ }^{9}$ Cf. fn. 19.

${ }^{10}$ To "reminiscent reflection", cf. Wiedebach [13. P. 67-70].
} 
determinations permeate Hegel's dialectical negativism. It is the definition of quantity based on the logic of being, and within it, the remarks on differential and integral calculus that are in the background here ${ }^{11}$. Didn't Cohen write in 1883 , somewhat perplexingly, that Hegel "made a critique of the infinitesimal concept the basis of his logic"? [14. P. 118-119] ${ }^{12}$ Nevertheless, he continues, "this exposition, covering hundreds of pages, cannot be dealt with in more detail here, because it" again too sweepingly - "is based on philosophical presuppositions which are far from us, farther than the philosophical views of Descartes and Leibniz" [14. P. 119].

Cohen's Principle of the Infinitesimal Method shows instead striking similarities with Hegel's Science of Logic both in the evaluation of historical authors and in the systematic discussion of the limit method or the differential quotient ${ }^{13}$. The intellectual approach of my study would require considering this observation strictly from the thought principle of continuity. It would be to trace on it the transition from Cohen's principle-logic of quality to the object-logic of quantity and then again to put the test to a comparison of the two authors. This would be, even if one disregards for a moment the complexity of the strongly growing material, already in the approach clearly more complicated than what has been attempted so far. This begins already with the fact that "quality" in Hegel's logic of being is something distinctly different from "quality" in Cohen, in whom it characterizes the "judgments of the laws of thought." It continues in a question imposed by a representational finding: by Hegel, "continuity," "self-continuity," etc., are discussed in an extraordinarily multifaceted application, but hardly as a logically pervasive principle. By Cohen, on the other hand, continuity is introduced as an original principle but is hardly explicated in its system-wide applications if one disregards the leading mathematical figure. While this seems to confirm Cohen's vehement demarcation, a detailed comparison finds the approach difficult.

\section{Translated from the German by Denis Chistyakov}

\section{References}

[1] Zeidler KW. Prolegomena zur Wissenschaftstheorie. Würzburg: Königshausen und Neumann; 2000.

[2] Zeidler KW. Stufen der Apriorität oder apriorische Synthesis? In: Zeidler KW, Krijnen C, editors. Reflexion und konkrete Subjektivität. Beiträge zum 100. Geburtstag von Hans Wagner (1917-2000). Vienna: Ferstl und Perz; 2017. p. 331-354.

\footnotetext{
${ }^{11}$ Cf. [9. Bd. 1. P. 179 ff.], especially the three extensive remarks on the "infinity of the quantum" [9. Bd. 1. P. 239-322], there see p. $254 \mathrm{ff}$. on the differential quotient dx/dy; supplementing also in conceptual logic the remark on mathematical analysis, chap. "Das universelle Urteil" [9. Bd. 2. 290 f.]. Further relations of continuity rich in relations and a multiple "continuation" are exposed both in the logic of essence [9. Bd. 2. P. 105, 113 f., 135, 143], as well as the logic of concepts [9. Bd. 2. P. 242, 270, 285] and elsewhere.

${ }^{12}$ Here (p. 119) is one of the few places where Cohen defends Hegel against attacks.

${ }^{13}$ Cf. also Prinzip der Infinitesimal-Methode [14] esp. Cohens "Jubiläums Betrachtungen", Teil 1 [15. P. 397-416]; cf. also "Das Urteil der Realität" [5. P. 121-144], and "Das Urteil der Allheit" [5. P. 174-209].
} 
[3] Wiedebach H. Widerspruch und Identität bei Cohen und Hegel. Schutz des Denkens vor Selbstvernichtung. In: Rendl M, König R, editors. Schlusslogische Letztbegründung. Festschrift für Kurt Walter Zeidler zum 65 Geburtstag. Berlin: Peter Lang; 2020. p. 297-306.

[4] Wiedebach H. Logic of Science vs. Theory of Creation: The 'Authority of Annihilation' in Hermann Cohen's Logic of Origin. The Journal of Jewish Thought and Philosophy. 2010;(18): 107-120.

[5] Cohen H. Werke. Bd. 6: System der Philosophie. Erster Teil: Logik der reinen Erkenntnis (2. Aufl. 1914). Holzhey H, editor. Hildesheim, Zürich, New York: Georg Olms, 2005.

[6] Holzhey H. Cohen und Natorp. Bd. 1. Basel/Stuttgart: Schwabe; 1986.

[7] Gordin J. Untersuchungen zur Theorie des unendlichen Urteils. Berlin: Akademie-Verlag; 1929.

[8] Cohen H. Kants Theorie der Erfahrung. In: Cohen H. Werke. Bd. 1.3: Erste Auflage 1871. Hildesheim, Zürich, New York: Georg Olms; 1987.

[9] Hegel GWF. Wissenschaft der Logik. Bd. 1-2. Lasson G, editor. Hamburg: Felix Meiner Verlag; 1963.

[10] Holzhey H. Entzauberung des Pantheismus. Cohens Kritik an Hegels und Schellings Metaphysik. In: Krijnen C, Pätzold D, editors. Der Neukantianismus und das Erbe des deutschen Idealismus. Die philosophische Methode. Würzburg: Königshausen und Neumann; 2002. p. 49-64.

[11] Bonsiepen W. Hegel und der Neukantianismus. In: Wyrwich T, editor. Hegel in der neueren Philosophie. Hamburg: Meiner; 2011. p. 47-112.

[12] Cohen H. Werke. Bd. 7: System der Philosophie. Zweiter Teil: Ethik des reinen Willens. Hildesheim, Zürich, New York: Georg Olms, 2012.

[13] Wiedebach H. The National Element in Hermann Cohen's Philosophy and Religion. Boston, Leiden: Brill; 2012.

[14] Cohen H. Werke. Bd 5/I: Das Prinzip der Infinitesimal-Methode und seine Geschichte. Ein Kapitel zur Grundlegung der Erkenntniskritik. Hildesheim, Zürich, New York: Georg Olms, 2012.

[15] Cohen H. Hermann Cohen's Schriften zur Philosophie und Zeitgeschichte. Bd. 1. Berlin: Akademie-Verlag; 1928.

\title{
About the author:
}

Wiedebach Hartwig - Dr. Phil., Privatdozent, Göppingen, Germany (e-mail: wiedebach@posteo.de).

\section{Защита мышления от самоуничтожения. Противоречие и тождество у Когена и Гегеля}

\section{Хартвиг Видебах $₫$}

\author{
Germany, 73033, Goeppingen, Georg-Boehringer-Weg, 37
}

\wiedebach@posteo.de

Аннотация. В «Логике чистого познания» Германа Когена и в «Науке логики» Г.В.Ф. Гегеля каждый по своему использует средства мышления отрицания и противоречия для развития философской динамики: хрупкого взаимодействия между угрозой самому себе и самосохранением мышления. Здесь проявляются близость и различие между двумя авторами. Близость кроется в методологическом негативизме; различие - 
в разной важности принципа непрерывности. Согласно и Когену, и Гегелю, мышление происходит исключительно, как называл его Кант, синтетическим путем. Исключение противоречия, которое ограничивается аналитическими суждениями, имеет лишь маргинальное значение. Но сходство не отменяет различий. Для Гегеля противоречие - это принцип опосредствования, который в конечном итоге ведет к «саморазрушению»; он несет в себе принцип логического «примирения». Для Когена противоречие - это принцип «уничтожения» (annihilatio) подходов к определению, которые угрожают каждой форме «тождества». Заложенный в самом противоречии поворот Гегеля, который видит в нем единство положительного и отрицательного, не имеет прямого эквивалента у Когена. Несмотря на это, «суждение противоречия» также становится у него активной основой всего познающего мышления. Производя разрушающую противоречие «деятельность», суждение противоерчия «защищает», да, «производит» реальную возможность познания. Уничтожение не-тождественного высвобождает, прежде всего, фундаментальное «суждение первоначала», с которого начинается познание. Он соответствует принципу непрерывности, заимствованному у Лейбница. Именно этому принципу у Гегеля нет прямого эквивалента.

Ключевые слова: аннигиляция, контрадикторность, диалектика, тождество, Якоб Гордин, суждение, законы мысли, негативизм, первоначало

\section{История статьи:}

Статья поступила 16.05.2021

Статья принята к публикации 04.09.2021

Для цитирования: Wiedebach $H$. Guarding Thought against Self-Destruction. Contradiction and Identity in Cohen and Hegel // Вестник Российского университета дружбы народов. Серия: Философия. 2021. Т. 25. № 3. С. 394 -403. DOI: 10.22363/2313-2302-2021-25-3394-403

\section{Сведения об авторе:}

Видебах Хартвиг - доцент, доктор философии, Гёппинген, Германия (e-mail: wiedebach@posteo.de). 